\title{
ВИЗНАЧАЛЬНІ АСПЕКТИ КРИМІНАЛІСТИЧНОЇ МЕТОДИКИ ЩОДО ВИЯВЛЕННЯ ТА РОЗСЛДУВАННЯ КРИМІНАЛЬНИХ ПРАВОПОРУШЕНЬ ЗА ОЗНАКАМИ ПЦДРОБКИ БРЕНДУ
}

\author{
ОСМОЛЯН Віталій Анатолійович - кандидат юридичних наук, старший \\ викладач кафедри права, Хмельницький кооперативний торговельно-економічний \\ інститут (місто Хмельницький)
}

УДК 343.98.06

DOI 10.32782/EP.2021.17

Излагаются правовъие основъ и перспективъи развития криминалистики в свете новъих криминальнылх угроз при стремительном развитии совершения уголовньхх правонарушений в сбере хозяйственной деятельности. Рассмотренъг прочессуально-правовъе и экспертно-криминалистические вотросъ по возможности вылвления, Фиксации и собирании следовой картинъ и бормировании доказательной базъ в совершении уголовньхх правонарушений в сђере хозяйственной деятельности, а также обоснована необходимость эфбективного содействия работников следственньхх органов, суда и пробильных спеицалистов компаний-владелии, бренда, а также Департамента зашить экономики Национальной полиции Украинъг для качественного и объективного въпполнения заданий уголовного производства и улучшение инноващионной политики Украинъл. Приведенъ конкретнъие примеры вопросов, которвие ставились на рассмотрение экспертам при проведении экспертизв в сбере интеллектуальной собственности, ито имело место на практике. Сделанъ въгводъ и предоставленъ рекомендащии по согласованному использованию норм действующего законодательства в практической деятельности специилиста-представителя компании владелищъ бренда и следователя. Обращено внимание на необходимость дальнейшего научного сотрудничества ученьх, спечиалистов в области материального и прочессуального права.

Ключевъге слова: криминалистика, уголовное правонарушение (преступление), метод, бренд, товарный знак, товарная марка, хозяйственная деятельность, инбормация, правоохранительнъие органъ, досудебное расследование, уголовное производство, экспертиза, эксперт, специалист.

\section{Постановка проблеми}

Розвиток товарного виробництва протягом останніх десятиріч призвів до перенасичення ринків товарами масового попиту. Проте товар, який є брендом, продається набагато краще, ніж його менш імениті аналоги. Виробники зрозуміли, що займатись впровадженням власного бренду у повсякденне життя пересічних громадян 3 метою отримання високих дивідендів у майбутньому - це один із перспективних напрямків ринкової економіки. Але розвиток будь-якої речі чи «образу» як у матеріальному, так і нематеріальному (віртуальному) світі людських відносин, яке $\epsilon$ джерелом високих прибутків, постає об'єктом заздрощів, а отже, мимоволі перетворюється на предмет кримінально протиправних посягань. Так, кримінальні правопорушення у сфері господарської діяльності є специфічним явищем кримінально протиправної діяльності, яке постійно розвивається 3 неминучим розвитком та удосконаленням технічного прогресу, а також нерозривно поєднане із економічною ситуацією та господарською діяльністю країни в цілому. Саме ця новизна та специфічність, неухильний та постійний розвиток незаконного використання знака для товарів і послуг, фірмового найменування, кваліфікованого зазначення походження товару (кримінального правопорушення, передбаченого статтею 229 Кримінального кодексу України [1]) вимагають від судових та правоохоронних органів, криміналістів удосконалення вже існуючих, розроблення та застосування нових криміналістичних засобів та методів у їх вияв- 


\section{Кримінальне право, кримінальний процес та криміналістика}

ленні та фіксації для подальшого невід'ємного використання у проведенні ефективного розслідування, встановленні та притягненні винних осіб до відповідальності.

Це покладає особливу відповідальність на правоохоронні органи щодо проведення якісного та легітимного досудового розслідування у кримінальних провадженнях зазначеної категорії, повного та неупередженого збору доказової бази, що не уявляється можливим без суворого дотримання процедури законності. У цьому і полягає актуальність проблеми.

\section{Аналіз останніх досліджень та публікацій}

Проведений аналіз [1-9] показав, що вчені неодноразово досліджували діяльність правоохоронних органів по збиранні доказової бази, проведенні криміналістичних дій у цілому та ії окремі аспекти зокрема. Проте розгляд процесуально-правових та експертно- криміналістичних питань щодо нових можливостей виявлення, фіксації та збирання слідової картини та формування в подальшому доказової бази щодо вчинення окремих видів кримінальних правопорушень у сфері господарської діяльності вимагає детального дослідження та аналізу.

Мета статті - на підставі проведеного теоретичного аналізу та власного практичного досвіду розглянути процесуально-правові та експертно-криміналістичні питання нових можливостей у виявленні, фіксації та збиранні слідової картини та формуванні доказової бази вчинення кримінальних правопорушень у сфері господарської діяльності, а саме: незаконного використання знака для товарів і послуг, фірмового найменування, кваліфікованого зазначення походження товару, а також обгрунтувати необхідність ефективної співпраці працівників слідчих органів, прокуратури та суду, а також Департаменту захисту економіки Національної поліції України для якісного та об'єктивного виконання завдань кримінального провадження та покращення інноваційної політики України взагалі.

Виклад основного матеріалу

Будівництво в Україні правової держави та європейсько-демократичного суспільства передбачає якісне зменшення порушень правопорядку, суттєве зменшення рівня злочинності, по можливості зменшення причин, що іï породжують.

Методика розслідування окремих видів кримінальних правопорушень як невід'ємний розділ сучасної системи криміналістики складається з системи наукових положень та розроблених на їх основі рекомендацій щодо процесу розкриття та розслідування кримінальних правопорушень.

3 урахуванням специфіки вчинення різного виду кримінальних правопорушень, вичерпний перелік яких надано законодавцем в Особливій частині Кримінального кодексу України [1], правоохоронцями та криміналістами-практиками вироблені та напрацьовані методичні рекомендації щодо специфіки розслідування певних категорій кримінальних правопорушень.

Проте, 3 неухильним розвитком технічного прогресу, який нерозривно поєднаний із економічною ситуацією та господарською діяльністю країни в цілому, неминуче «удосконалюються» способи вчинення кримінальних правопорушень у сфері господарської діяльності, що, у свою чергу, постає причиною удосконалення методики розслідування кримінальних правопорушень вказаної категорії, каталізує пошук інновацій у цьому розділі загальної системи криміналістики.

Безсумнівною інновацією у методиці розслідування кримінальних правопорушень у сфері господарської діяльності, а саме: незаконного використання знака для товарів і послуг, фірмового найменування, кваліфікованого зазначення походження товару є залучення слідчим на етапі проведення першопочаткових слідчих дій як профільних спеціалістів представників компаній-власниць бренду (у науковій статті для прикладу зроблено посилання на дочірне підприємство «АДЦДАС-УКРАЇНА», місто Київ [2]), а також працівників Департаменту захисту економіки Національної поліції України [3] з метою виявлення та документування кримінально протиправної діяльності на вказаній ділянці правового поля, що, у свою чергу, є гарантом якісного та об'єктивного виконання завдань Кримінального процесуального кодексу України [4]. 
Так, участь спеціаліста у досудовому розслідуванні в межах кримінального провадження регламентована статтями 71-72, 79 Кримінального процесуального кодексу України [4].

Необхідно зазначити, що виділення профільного спеціаліста можливе в разі наявності у правоохоронного органу відкритого кримінального провадження за ознаками виготовлення несправжньої, контрафактної, збиткової продукції для компаній із зареєстрованим брендом, шляхом незаконного використання належних їм знаків для товарів та послуг іншими суб'єктами господарської діяльності 3 метою власного незаконного збагачення.

На рівні процесуального права однією 3 підстав для відкриття кримінального провадження частіше за все виступають власні дослідження та звернення представництв компаній-власників бренду до правоохоронних органів $з$ приводу того, що речі, які направлені їм на дослідження фізичними або юридичними особами (в т.ч. правоохоронними установами) iз логотипами торгової марки компанії-власниці бренду, не виготовлялись компанією, а тому не відповідають оригінальним продуктам; компанія вважає їх фальсифікованими, а, відповідно, дії суб'єктів господарювання по випуску та реалізації зазначеної продукції $є$ незаконними та збитковими для останньої (у цьому випадку представництва компанії-власниці бренду зазначають спричинену матеріальну шкоду незаконними діями суб'єктів господарювання, яка у відповідності до вимог статті 229 Кримінального кодексу України повинна завдати компанії матеріальну шкоду у значному розмірі, т.б. іï розмір у двадцять і більше разів повинен перевищувати неоподатковуваний мінімум доходів громадян [1]).

У сучасному світі відсутне єдине визначення поняття «бренду» та невід'ємних його складових «брендингу, товарного знаку та товарної марки». Зокрема, під цими поняттями розкривають наступне.

Так, бренд - це «розкручений» товарний знак, його імідж, який виникає внаслідок різних маркетингових дій [5, с.11].

Або бренд - це найважливіша відмінна властивість товару [6, с. 13].

А також бренд - це символ, дизайн, знак, назва, 3 якими ототожнюють товар або по- слуги. Бренд у сучасному розумінні є образом товару в уявленні споживача, який дозволяє останньому обирати той чи інший товар, тобто позиціонує собою деякий образ товару, який має зміст та сенс, що мають значення для споживача [7, с. 119].

Брендинг - це системний, обгрунтований, виважений процес, що передбачає планування та впровадження маркетингового комплексу заходів щодо створення торговельної марки, розроблення плану перетворення торговельної марки на бренд, зокрема шляхом розроблення відповідного імені, корпоративного стилю та дизайну, рекламних кампаній, проведення акцій зі стимулювання збуту, цілеспрямованого PR, з метою формування бажаних асоціативних вражень у споживачів [8, с. 13].

Товарна марка - це назва, термін, знак, символ чи їх комбінація, призначені для того, щоб ідентифікувати продукт та диференціювати його від продуктів конкурентів [5, с. 19].

Товарний знак - це зареєстровані у встановленому законодавцем порядку на ім'я володільця символ, слово, зображення, звукові позивні чи оригінальна форма та зафіксований набір характеристик та особливостей, які слугують для однозначної ідентифікації товару [5, c.19].

Тому 3 метою подальшого виявлення, фіксації слідів порушень вимог законодавства щодо захисту товарної марки, товарного знаку, бренду, а також встановлення та підтвердження наявності ознак кримінального правопорушення, передбаченого статтею 229 Кримінального кодексу України «Незаконне використання знака для товарів і послуг, фірмового найменування, кваліфікованого зазначення походження товару», правоохоронним органам доцільно призначити експертизу у сфері інтелектуальної власності (торговельних марок - знаків для товарів і послуг, фірмових найменувань, зазначення походження товаpiв).

Експертиза у сфері інтелектуальної власності встановлюе фактичні дані про властивості, ознаки, закономірності створення та використання об'єктів, що за своєю природою є нематеріальними об'єктами, але набувають правової охорони при дотриманні всіх установлених законодавством умов і фіксації в певній об’єктивній (матеріальній) формі. 


\section{Кримінальне право, кримінальний процес та криміналістика}

Призначення та проведення експертиз у сфері інтелектуальної власності проводиться за правилами, що передбачені для будь-яких видів експертиз.

Орієнтовний перелік питань, які можуть бути поставлені на вирішення експерту у сфері інтелектуальної власності наводиться в Науково-методичних рекомендаціях 3 питань підготовки та призначення судових експертиз та експертних досліджень [9]. Вказаний перелік не $\epsilon$ вичерпним. У зв'язку із накопиченням криміналістичної та експертної практики до переліку питань цього класу судової експертизи постійно вносяться відповідні зміни й доповнення.

Зокрема, під час проведення експертизи у сфері інтелектуальної власності встановлюються (на прикладі підробки продукий ДП «АДІДАСУКРАЇНА» компанї̈ «Adidas International Marketing B.V.» ma «Adidas AG» иляхом незаконного використання належних їм знаків для товарів та послуг "\#, «Adidas», «») наступні ключові моменти, які мають вирішальне значення для подальшої кваліфікації кримінального правопорушення та векторного направлення розслідування кримінального провадження:

Чи є позначення «", «Adidas», «», що наявні на виявленому та вилученому під час слідчих (розшукових) дій в місцях реалізації контрафактної продукції (товарів), тотожними або схожими настільки, що їх можна сплутати із знаками для товарів та послуг "», «Adidas», «» (необхідно вказати свідочтва, щь діють на територіӥ Украӥни №№....), права, які належать компанії «Adidas AG»?

Чи є позначення «", «Adidas», «», що наявні на виявленій та вилученій продукції, такими, що можуть ввести в оману щодо товару, послуги або особи, яка виробляє/продає товар або надає послугу?

Який розмір матеріальної шкоди завдано компанії «Adidas AG» внаслідок використання знаків для товарів та послуг «", «Adidas», « ”

Як висновок до статті зазначимо, що, на нашу думку, кримінальні правопорушення у сфері господарської діяльності, а саме: незаконне використання знака для товарів і по- слуг, фірмового найменування, кваліфікованого зазначення походження товару - $є$ досить специфічним явищем кримінально протиправної діяльності, яка постійно розвивається 3 неминучим розвитком технічного прогресу та господарської діяльності держави. Саме ця новизна та специфічність, неухильний та постійний розвиток вказаного виду кримінальних правопорушень вимагають від судових та правоохоронних органів, криміналістів розроблення та застосування нових криміналістичних засобів та методів у їх виявленні та фіксації для подальшого невід'ємного використання у проведенні ефективного розслідування, встановленні та притягненні винних осіб до відповідальності.

Зважаючи на наявність недоліків у цій сфері процесуально-правової та експертно-криміналістичної діяльності вважаємо за актуальні подальші дослідження відповідної спрямованості, адже останні створюватимуть перспективи теоретичних та практичних напрацювань та сприятимуть розв'язанню проблемних питань на цьому напрямку.

\section{Лiтература}

1. Кримінальний кодекс України. Закон України від 5 квітня 2001 року №2341-III (редакція станом на 20.01.2021) [Електронний ресурс] : http://zakon.rada.gov.ua (дата звернення: 20.01.2021).

2. Дочірне підприємство «АДІДАСУКРАЇНА» (Україна, м. Київ, вул. Гарматна, буд. 4, код СДРПОУ 24251899, дата реєстрації 28.05.1996) - засновник юридичної особи: акціонерне товариство «АДІДАС АГ» (Німеччина, АДІ-ДАССЛЕР ШТР., ГЕРЦОГЕНАУРАХ) [Електронний ресурс]: http://youcontrol.com.ua (дата звернення: 20.01.2021).

3. Департамент захисту економіки Національної поліції України [Електронний pecypc] : http://www.npu.gov.ua (дата звернення: 20.01.2021).

4. Кримінальний процесуальний кодекс України. Закон України від 13 квітня 2012 року №4651-VI (редакція станом на 20.01.2021). [Електронний ресурс] : http://zakon.rada.gov.ua (дата звернення: 20.01.2021).

5. Мазилкина Е. И., Брендинг: Учебнопрактическое пособие / Е.И. Мазилкина. - 2-е узд. - М.: Издательско-торговая кор- 


\section{АНОТАЦІЯ}

Викладаються правові основи та перспективи розвитку криміналістики в світлі нових кримінальних загроз при стрімкому поширенні вчинення кримінальних правопорушень у сбері господарсъкої діяльності. Розглянуто процесуально-правові та експертно-криміналістичні питання щодо можливості виявлення, біксаиї та збирання слідової картини та бормуванні доказової бази у вчиненні кримінальних правопорушень у сфері господарськой діяльності, а також обгрунтовано необхідність ефективної співпрачі прачівників слідиих органів, суду та пробільних спещіалістів компаній-власниць бренду, а також Департаменту захисту економіки Національної поліизї України для якісного та об'єктивного виконання завдань кримінального провадження та покращення інновачійної політики Украйни. Наведені конкретні приклади завдань, які ставились на вирішення експертам при проведенні експертизи у сфері інтелектуальної власності, що мало місие на практиці. Зроблені висновки та надані рекомендащиї щодо узгодженого застосування норм діючого законодавства у практичній діяльності спеціаліста-представника компанії власнищі бренда та слідчого. Привернуто увагу на необхідність подальшої наукової співпраці вчених, спеціалістів у галузі матеріального та процесуального права.

Ключові слова: криміналістика, кримінальне правопорушення (злочин), метод, бренд, товарний знак, товарна марка, господарська діяльність, інформачія, правоохоронні органи, досудове розслідування, кримінальне провадження, експертиза, експерт, спеціалiсm.

порация «Дашков и Ко»; Саратов : АА ООО «БизнесВолга», 2011. - 224 с.

6. Стифб Д., Продавай больше, используй силу бренда : Практическое руководство / Пер. с англ. - М.: Издательский дом «Гребенников», 2009. - 264 c.

7. Макашева 3. М., Макашев М. О., Брендинг: Учебное пособие. - СПб.: Питер, 2011. - 288с.: - (Серия «Учебное пособие»).

8. Шульгіна А. М., Аео М. В., Брендинг : теорія та практика (на прикладі об'єктів ко- мерційної нерухомості) [Текст] : монографія / А.М. Шульгіна, М.В. Аео; Нац. техн. ун-т України «КПІ», Київ. Нац. торг.-екон. ун-т, Європейський ун-т. - Київ-Тернопіль : Астон, 2011. - 272 c.

9. Наказ Міністерства юстиції України від 08.10.1998 №53/5 «Про затвердження Інструкції про призначення та проведення судових експертиз та експертних досліджень та Науково-методичних рекомендацій $з$ питань підготовки та призначення судових експертиз та експертних досліджень» (редакція станом на 20.01.2021) [Електронний ресурс] : http:/ zakon.rada.gov.ua (дата звернення: 20.01.2021).

\section{Osmolian, V.A. \\ DEFINING ASPECTS OF FORENSIC METHODOLOGY FOR DETECTING AND INVESTIGATING CRIMINAL OFFENSES ON THE GROUNDS OF BRAND COUNTERFEITING}

In the article the author lays out the basics and prospects for the development of criminology in the light of new criminal threats with the rapid spread of crimes in the sphere of economic activity. Procedural-legal and expert-criminological issues concerning the possibility of detection, fixation and collection of a trace picture and formation of an evidence base in commission of crimes in the sphere of economic activity are considered. And also the necessity of effective cooperation of employees of investigative bodies of court and profile specialists of the brand owners, as well as the Department of Economic Protection of the National Police of Ukraine for qualitative and objective performance of tasks of criminal proceedings and improvement of innovation policy of Ukraine is substantiated. Giving specific examples of tasks that were set for experts to conduct during the examination in the field of intellectual property, witch took place in practice. Conclusions are made and recommendations are given on the coordinated application of the current legislation in the practice of a specialist-representative of the brand owner and investigator. Attention is drawn to the need for further scientific cooperation of scientists, specialists in the field of substantive and procedural law.

Keywords: criminalistics (criminology), crime, method, brand, trademark, economic activity, information, criminal proceedings, police, pre-trial investigation, expertise, expert, specialist. 